\title{
Polymorphisms in sweet taste genes (TAS1R2 and GLUT2), sweet liking, and dental caries prevalence in an adult Italian population
}

\author{
Antonietta Robino $^{1}$ Lorenzo Bevilacqua ${ }^{2}$ Nicola Pirastu ${ }^{1,2} \cdot$ Roberta Situlin $^{3}$. \\ Roberto Di Lenarda $^{2}$ Paolo Gasparini ${ }^{1,2}$ - Chiara Ottavia Navarra ${ }^{2}$
}

Received: 20 November 2014/ Accepted: 4 August 2015/Published online: 13 August 2015

(C) Springer-Verlag Berlin Heidelberg 2015

\begin{abstract}
The aim of the study was to assess the relationship between sweet taste genes and dental caries prevalence in a large sample of adults. In addition, the association between sweet liking and sugar intake with dental caries was investigated. Caries was measured by the decayed, missing, filled teeth (DMFT) index in 647 Caucasian subjects (285 males and 362 females, aged 18-65 years), coming from six villages in northeastern Italy. Sweet liking was assessed using a 9-point scale, and
\end{abstract}

Electronic supplementary material The online version of this article (doi:10.1007/s12263-015-0485-z) contains supplementary material, which is available to authorized users.

Antonietta Robino

antonietta.robino@burlo.trieste.it

Lorenzo Bevilacqua

1.bevilacqua@fmc.units.it

Nicola Pirastu

nicola.pirastu@burlo.trieste.it

Roberta Situlin

robertasit@tiscali.it

Roberto Di Lenarda

r.dilenarda@fmc.units.it

Paolo Gasparini

paolo.gasparini@burlo.trieste.it

Chiara Ottavia Navarra

c.navarra@fmc.units.it

1 Institute for Maternal and Child Health - IRCCS "Burlo Garofolo", Via dell'Istria 65/1, 34137 Trieste, Italy

2 Department of Medical Sciences, University of Trieste, Piazza dell'Ospitale, 1, 34125 Trieste, Italy

3 Department of Medical Sciences, Institute of Clinical Medicine, University of Trieste, Strada di Fiume 447, 34149 Trieste, Italy the mean of the liking given by each individual to specific sweet food and beverages was used to create a sweet liking score. Simple sugar consumption was estimated by a dietary history interview, considering both added sugars and sugar present naturally in foods. Our study confirmed that polymorphisms in TAS1R2 and GLUT2 genes are related to DMFT index. In particular, GG homozygous individuals for rs3935570 in TAS1R2 gene $(p$ value $=0.0117)$ and GG homozygous individuals for rs1499821 in GLUT2 gene ( $p$ value $=0.0273$ ) showed higher DMFT levels compared to both heterozygous and homozygous for the alternative allele. Furthermore, while the relationship sugar intake-DMFT did not achieve statistical significance ( $p$ value $=0.075$ ), a significant association was identified between sweet liking and DMFT ( $p$ value $=0.004)$, independent of other variables. Our study showed that sweet taste genetic factors contribute to caries prevalence and highlighted the role of sweet liking as a predictor of caries risk. Therefore, these results may open new perspectives for individual risk identification and implementation of target preventive strategies, such as identifying high-risk patients before caries development.

Keywords Sweet food liking $\cdot$ Sugar intake $\cdot$ Sweet taste genes $\cdot$ DMFT $\cdot$ Dental caries prevalence

\section{Introduction}

Dental caries is one of the most prevalent multifactorial diseases worldwide, prompting the World Health Organization (WHO) to consider its care and prevention as priority for the new millennium (Martin et al. 2003; WHO official Web site). 
The caries starts when the acids produced by the metabolic degradation of the sugar by oral commensals bacteria dissolve the tooth mineral matrix. The etiology of caries involves oral microflora composition, diet and oral hygiene habits, and host determinants, which are affected by the synergic coexistence of multiple sociological and environmental factors, such as fluoride exposure and access to preventive dental care (Holst et al. 2001; Moynihan and Petersen 2004; Touger-Decker and Mobley 2003).

Evidence from animal and human studies has revealed that amount and frequency of sugar intake are the most important dietary factors in caries development. Furthermore, increased sugar consumption is associated with a higher level of caries prevalence (Sreebny 1982; Krasse 2001). The first studies on rats showing a significant correlation between sugar concentration and caries incidence were described in the 1970s (Mikx et al. 1975; Hefti and Schmid 1979). A large number of studies conducted in different human populations have confirmed this strong relationship (Arnadottir et al. 1998; Beighton et al. 1996; Bruening et al. 1999; Burt et al. 1988; Gibson and Williams 1999; Jones et al. 1999; Masalin et al. 1994; Kalsbeek and Verrips 1994; Creedon and O’Mullane 2001; Vanobbergen et al. 2001; Lim et al. 2008).

Moreover, it has been demonstrated that the probability of developing caries increases by $1 \%$ every $5 \mathrm{~g}$ of daily sugars intake in school children with a low-calorie diet (Szpunar et al. 1995). Assuming that a greater preference for sweet leads to a higher sugar intake, the positive association between taste preference for sweet foods and dental caries was also investigated (Szpunar et al. 1995; Steiner et al. 1984). Jamel et al. (1997) found also correlation between sweet preferences, sweet tea consumption, and dental caries.

These studies have been conducted mainly on children and adolescents (Jamel et al. 1997; Steiner et al. 1984) or on elderly people (MacEntee et al. 1993); both groups (children and elderly) are known to have a higher sugar intake. However, very few studies have taken into account adult populations.

Genetic factors also play an important role in dental caries development. Heritability and twin studies have confirmed that genetic factors account for 50-70\% of phenotypic variation in caries prevalence in primary dentition, while for 35-55 \% in permanent dentition (Conry et al. 1993; Bretz et al. 2005; Wang et al. 2012). In this light, several genes involved in tooth formation and development, immunological system, and salivary proteins have been investigated as possible candidates, but only few of them associated with the disease (Slayton et al. 2005; Deeley et al. 2008; Azevedo et al. 2010; Wang et al. 2012; Küchler et al. 2013; Wendell et al. 2010).
The literature has also investigated whether the genes responsible for taste perception and preferences could influence caries insurgence. For example, several studies have supported the association between genetic variations in the bitter taste receptor gene TAS2R38 and caries risk (Wendell et al. 2010). Three single nucleotide polymorphisms (SNPs) in this gene guide the capacity to perceive specific bitter compounds, including PTC (phenylthiocarbamide) and PROP (6- $n$-propylthiouracil) (Kim et al. 2003). Furthermore, it has been shown that differences in the perception of PROP and/or PTC can affect a variety of taste sensations, such as oral irritation of capsaicin, fat perception, and sweetness, and can influence food preferences and intake (Tepper 2008; Dinehart et al. 2006; Keller et al. 2002). Therefore, also through these influences on dietary preferences and intake, TAS2R38 gene may determine caries development.

Recently, a statistically significant association between genetic variants in TAS1R2 (sweet taste receptor) and GLUT2 (glucose transporter) genes, both involved in sweet taste perception, with caries risk was described in a sample of young adults (80 individuals) with high level of dental care (Kulkarni et al. 2013). However, to date no studies on a population of wide age range adults have been conducted in this field.

The aim of the present study was to analyze whether in a large population of adults (647 individuals) there is an association between individual caries susceptibility, determined with the decayed, missing, filled teeth (DMFT) index, a measure of caries prevalence, and (1) polymorphisms in TAS1R2 and GLUT2 genes; (2) sweet food liking; and (3) simple sugar intake.

\section{Materials and methods}

\section{Participants}

Data of 647 Caucasian individuals aged 18-65 years were collected thanks to the "Friuli-Venezia Giulia Genetic Park" project, aimed at analyzing a series of villages located in the northeast of Italy (San Martino del Carso, Erto e Casso, Clauzetto, Illegio, Sauris, and Val di Resia) showing evidence of isolation due to geographical, historical, linguistic, and/or cultural factors (Esko et al. 2013). Participants gave written informed consent, and the ethical committee of IRCCS Burlo Garofolo approved the study (Prot. CE/V-78, 06/08/2007).

\section{Sweet food liking measurement}

Food likings were evaluated using a 45-item food liking questionnaire, already used in a previous study (Pirastu 
et al. 2014). Subjects were invited to rate their food liking for different sweet foods or beverages using a 9-point scale ranging from "like extremely" (score 9) to "dislike extremely" (score 1). The option "never tried" was also included in the questionnaire (Peryam and Pilgrim 1957). Peculiar sweet foods and beverages were explicitly indicated into the questionnaire: marzipan, panettone (typical Italian sweet bread), whipped cream, ice cream, milk chocolate, espresso with sugar.

All these sweet foods included in the questionnaire were used to construct a sweet food group $(\alpha=0.64)$. For each individual, a sweet liking score was defined as the mean of the liking given by each individual to the foods belonging to the sweet group. This score was used in the subsequent statistical analysis.

For statistical analyses, the individuals reporting that they had never tried sweet foods in the liking questionnaire were excluded.

\section{Sugar intake assessment}

A subsample of 322 subjects agreed to complete a dietary history to assess simple sugar consumption. The habitual food intake was measured by a detailed dietary history interview method (Schmidt et al. 1994), conducted by professionals. The interview evaluated the average daily food intake of each subject, considering the habitual meal patterns, i.e., the usual food and drink choices during major meals and snacks of a normal day. This method took into account also the frequency of food and drink consumption outside the normal daily intake (e.g., weekends and holidays). To help subjects to define more accurately their food portion sizes, visual aids were provided, including a picture atlas with three different size portions for each major food category and common household items (tablespoons, teaspoons, cups and glasses of different volumes). A frequency checklist was also administered to detect omissions or imprecisions about some food items more difficult to recall or to specify, such as condiments, used in cooking or dressing, added sugars, for example to drinks, alcohol, or foods eaten outside meals or from takeaways. This allows a further checking and gives the possibility to correct contradictory reports. Nutrient intake was then assessed through a software (WinFood, 2.7. Medimatica, San Benedetto del Tronto, Italy) based on Italian food composition tables.

In particular, simple sugar consumption was assessed considering both added sugars (extrinsic simple sugars) and sugar present naturally in foods (intrinsic simple sugars).

\section{Dental caries assessment}

An accurate oral clinical examination of the participants was conducted by expert dentists. The number of DMFT was recorded according to the recommendations of the WHO for epidemiological surveys, moreover the overall number of teeth present in the mouth. An additional X-ray examination (panoramic radiography) was performed in order to detect the misleading carious lesions. Wisdom teeth were excluded.

\section{Genotyping}

For each sample, DNA was extracted from peripheral blood and genotyping was carried out using Illumina $370 \mathrm{k}$ high-density SNP array (Illumina, Inc., San Diego, CA, USA) (Howie et al. 2012). All the SNPs genotyped inside TAS1R2 and GLUT2 genes were analyzed. The number of SNPs investigated for each gene is reported in Supplementary Table S1.

\section{Statistical analyses}

The associations between sweet food liking and sugar consumption with DMFT were tested by fitting a linear model where the DMFT was considered as the dependent variable while sweet food liking or sugar consumption as regressors. Sex, age, and BMI were used as covariates in the analysis.

Association analysis for the SNPs in sweet genes (TAS1R2 and GLUT2) was conducted using linear mixed model regression analysis where DMFT was used as the dependent variable and the each SNP as the independent variable. As random effect, the genomic kinship matrix between all subjects estimated with the $i b s$ function in GenABEL was used. Sex and age were also used as covariates. Association analysis was conducted using the GRAMMAR + method as implemented in the GenABEL (Aulchenko et al. 2007).

\section{Results}

\section{Participant characteristics}

Main features of participants in terms of demographics, age groups, BMI classification, and genotypes are reported in Table S2 and Table S3. The mean age of the study sample was $44.9 \pm 12.4$ (range 18-65 years). Forty-four percentage $(n=285)$ of the participants were males, and $56 \%$ $(n=362)$ were females. The DMFT mean in the overall sample is $15.8 \pm 7.3$ (Table 1 ), in agreement with a recent work showing that DMFT in different populations (UK, USA, Japan, and Sweden) ranges approximately from 7 to 23 in adults (Bernabé and Sheiham 2014). DMFT index did not vary significantly with subjects' BMI, while significant differences were detected in terms of sex and age (Table S4). 
Table 1 Mean and standard deviation of sample characteristics

\begin{tabular}{llll}
\hline & $\begin{array}{l}\text { All } \\
(n=647)\end{array}$ & $\begin{array}{l}\text { Male } \\
(n=285)\end{array}$ & $\begin{array}{l}\text { Female } \\
(n=362)\end{array}$ \\
\hline Age (years) & $44.9 \pm 12.4$ & $45.7 \pm 12.5$ & $44.4 \pm 12.2$ \\
Teeth $(n)$ & $23.1 \pm 6.4$ & $22.6 \pm 7.0$ & $23.5 \pm 6.0$ \\
DMFT & $15.8 \pm 7.3$ & $15.7 \pm 7.2$ & $16.0 \pm 7.3$ \\
Sweet liking score & $6.61 \pm 1.30$ & $6.60 \pm 1.35$ & $6.62 \pm 1.27$ \\
BMI $\left(\mathrm{kg} / \mathrm{m}^{2}\right)$ & $25.1 \pm 4.5$ & $26.3 \pm 3.9$ & $24.2 \pm 2.4$ \\
\hline & $(n=322)$ & $(n=149)$ & $(n=173)$ \\
\hline Simple sugar intake & $101.8 \pm 49.1$ & $107.2 \pm 53.8$ & $97.2 \pm 44.4$ \\
$(\mathrm{~g} / \text { die })^{\mathrm{a}}$ & & &
\end{tabular}

${ }^{a}$ Simple sugar intake is available in a subsample of 322 individuals

In the present study, the mean liking score for the food sweet group ranged from 1.2 to 9 with a mean of $6.61 \pm 1.30$ (Table 1).

Simple sugar intake in our sample showed a mean of $101.8 \pm 49.1 \mathrm{~g} / \mathrm{die}$ (Table 1). Similar values were already reported in other studies that took into account how genetic variants in sweet taste genes affect sugars consumption (Eny et al. 2008, 2010).

No gender and sex differences were found based on sweet food liking score and simple sugar intake. BMI also did not affect these nutritional variables in our population (Table S4).

The distribution of DMFT, sweet liking, and simple sugar intake is shown in supplementary materials (Figure S1, Figure S2, Figure S3).

\section{Association between variations in TAS1R2 and GLUT2 genes and DMFT}

Genetic association analysis detected a significant association with rs3935570, a SNP in the TAS1R2 gene $(p=0.0117)$, taking into account sex and age. As shown in Fig. 1, individuals homozygous for the allele $G$ showed higher DMFT compared to both heterozygous G/T and homozygous for the allele T. In addition, rs1499821 in the GLUT2 gene was associated with DMFT $(p=0.0273)$. Individuals homozygous for the allele $\mathrm{G}$ showed higher DMFT compared to both heterozygous G/A and homozygous A/A (Fig. 2). Complete results for all the analyzed SNPs are shown in Table 2.

\section{Association between sweet food liking and DMFT}

Using the whole sample, a significant association between DMFT and sweet food liking was found ( $p$ value $=0.003$ ), taking into account sex, age, and BMI. Table S5 shows the effect of covariates in regression analysis between DMFT

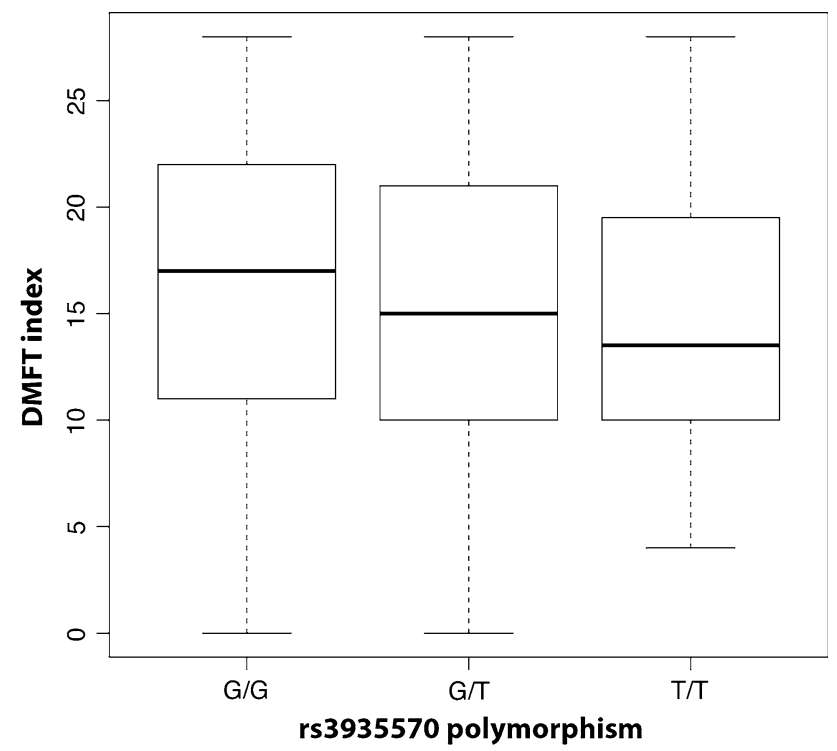

Fig. 1 Boxplot comparing DMFT for the genotypes at rs 3935570 SNP (figure was obtained by using the entire sample, $n=647$ )

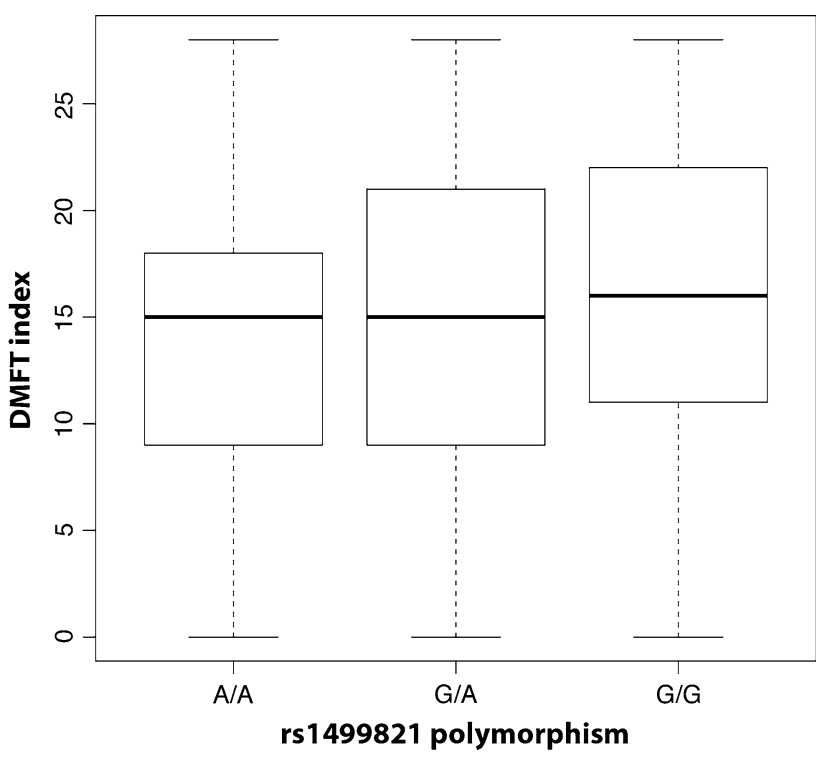

Fig. 2 Boxplot comparing DMFT for the genotypes at rs1499821 SNP (figure was obtained by using the entire sample, $n=647$ )

and sweet liking or simple sugar intake. Supplementary Figure S4 and S5 display QQ plot of residuals from the regression analysis of food liking and sugar consumption, respectively.

In particular, our analysis revealed that individuals with higher liking for sweet food showed higher DMFT values.

Using a subsample of 322 for which both liking and consumption of sweet foods were available, we confirmed the significant association between liking of sweet foods and DMFT previously observed ( $p$ value $=0.004$ ). Also in this case, sex, age, and BMI were considered as covariates. 
Table 2 Results of the association analysis of DMFT in the entire sample (number of individuals $=647$ )

\begin{tabular}{lllllll}
\hline SNP & Chromosome & \multicolumn{1}{l}{ Position } & \multicolumn{1}{l}{ Beta } & MAF & $p$ & Gene \\
\hline rs3935570 & $\mathbf{1}$ & $\mathbf{1 9 1 6 7 3 7 1}$ & $\mathbf{- 0 . 9 3 7}$ & $\mathbf{0 . 3 1 6 8}$ & $\mathbf{0 . 0 1 1 7}$ & TAS1R2 \\
rs1499821 & $\mathbf{3}$ & $\mathbf{1 7 0 7 2 4 7 2 9}$ & $\mathbf{- 1 . 0 4 7}$ & $\mathbf{0 . 1 6 7 6}$ & $\mathbf{0 . 0 2 7 3}$ & GLUT2 \\
rs5398 & 3 & 170715830 & -0.508 & 0.2797 & 0.2040 & GLUT2 \\
rs5400 & 3 & 170732300 & 0.422 & 0.1136 & 0.4526 & GLUT2 \\
rs11924032 & 3 & 170735099 & -0.378 & 0.2426 & 0.3595 & GLUT2 \\
\hline
\end{tabular}

Beta, effect of the effect allele; MAF, minor allele frequency; $p, p$ value

Significant results are reported in bold
Table 3 Regression analysis between DMFT and sweet intake and liking

\begin{tabular}{llll}
\hline & \multicolumn{3}{l}{ DMFT caries prevalence } \\
\cline { 2 - 4 } & $R^{2}$ & Beta estimate & $p$ value \\
\hline Simple sugar intake & 0.22 & 0.01 & 0.075 \\
Sweet liking & $\mathbf{0 . 2 6}$ & $\mathbf{0 . 6 1}$ & $\mathbf{0 . 0 0 4}$ \\
\hline
\end{tabular}

Significant results are shown in bold. Sex, age, and BMI were used as covariates

The results we reported were derived from the subsample of 322 individuals with both sugar intake and sweet liking data

Our results showed also that there was a positive correlation between sweet liking and simple sugar intake $(p$ value $=0.0001)$. Despite this, the association between intake of simple sugars and DMFT did not achieve statistical significance $(p$ value $=0.075$ ), although the sugar intake-DMFT relationship was in the same direction as the sweet liking-DMFT relationship (Table 3).

\section{Discussion}

Dental caries is one of the most common diseases in the world (Vos et al. 2012; Marcenes et al. 2013), and its treatment is very expensive (Petersen 2008). It has been demonstrated that the majority of caries occurs in adults and their prevalence increases as people get older (Bernabé and Sheiham 2014; Broadbent et al. 2006, 2013). Diet is one of the primary factors to influence chronic conditions or pathologies, such as cardiovascular disease, obesity, and caries. Therefore, it could have important public health consequences to better define the pattern of taste preferences and genetics of taste perception among the population. Recently, taste receptor genes have been associated with alcohol intake or sensations (Allen et al. 2013, 2014; Hayes et al. 2011, 2013; Duffy et al. 2004), incidence of myocardial infarction (Shiffman et al. 2008), or vegetable consumption (Sacerdote et al. 2007; Duffy et al. 2010; Colares-Bento et al. 2012).
Regarding dental caries, for example, Wendell and coworkers have already reported that genetic variants in TAS2R38 and TAS1R2 taste genes may affect caries risk through their impact on dietary preferences and habits (Wendell et al. 2010).

In the present work, the relationship between TAS1R2 and GLUT2 sweet taste genes and dental caries prevalence was tested in an adult population coming from a series of genetically isolated villages. In agreement with a recent work (Kulkarni et al. 2013), we have found that polymorphisms in these two genes are associated with DMFT in a very large sample cohort. The TAS1R2 receptor is responsible for sweet taste sensitivity (Nelson et al. 2001), while GLUT2 is a glucose transporter involved in the regulation of postprandial glucose levels (Brown 2000). Polymorphisms in both of these genes are responsible for individual differences in sweet perception and have been already linked to sugar consumption (Eny et al. 2008, 2010). In particular, a previous study has reported an association between rs35874116 SNP in the TAS1R2 gene and sugar intake in overweight and obese individuals (Eny et al. 2010). Also, the r5400 polymorphism in GLUT2 gene was already linked to higher than usual sugar consumption, suggesting that this glucose transporter, affecting glucose homeostasis, may also control food intake behavior (Eny et al. 2008).

Our study revealed that GG homozygous individuals for both rs3935570 SNP in TAS1R2 gene and rs1499821 SNP in GLUT2 gene showed higher DMFT caries scores. Compared to Kulkarni's study, our work has revealed that different polymorphisms in TAS1R2 and GLUT2 genes are associated with dental caries risk/protection. A possible reason for this dissimilarity is that we analyzed only $1 \mathrm{SNP}$ in TAS1R2 gene, while rs35874116 SNP studied by Kulkarni and colleagues was not genotyped in our study. Instead, rs5400 SNP in GLUT2 gene of Kulkarni's work was genotyped, but it was not statistically significant in our data. This difference is possibly due to a different origin of the population, or to a founder effect.

We did not observe in our population differences between the two identified SNPs and sugar intake. This 
lack of association may be due, for example, to the method employed to measure sugar intake.

So, we identified a direct association between variants in TAS1R2 and GLUT2 genes and caries prevalence, suggesting and further confirming that sweet taste genes may affect cariogenic status and caries development. However, whether this relation is mediated by the impact of these genes on dietary and nutritional habits remains unclear from our results, as already supposed, for example, for TAS2R38 gene (Wendell et al. 2010).

Moreover, the present study examined at the same time the relationship between sweet food liking and sweet food intake on dental caries prevalence. In this work, a positive association was found between DMFT and sweet food liking. However, the relationship between DMFT and the reported sweet intake did not reach statistical significance, although a positive correlation between sweet liking and sweet intake was observed. Although there is a general increase in the consumption of refined sugar and of sweet foods and drinks worldwide, sweet liking is not homogeneous across people and populations. The association between sweet taste preferences and dental caries is still controversial (Bretz et al. 2006). Surprisingly enough, our work revealed a positive correlation only between DMFT and sweet food liking but not with reported simple sugar intake in adults. Our finding can be related to a number of factors. First of all, simple sugars in the diet include both extrinsic (added to foods) and intrinsic (naturally present in foods, like in fruits and milk) sugars and derive from a variety of products of different nutrient composition with possible differential impact on decay promotion. Furthermore, through our results we have supported recent studies that demonstrate how food preferences, rather than food intake, predict health outcomes more accurately (Duffy et al. 2007, 2009). This is probably due to the fact that quantifying food consumption in terms of frequency and amount can be difficult based on dietary records. The personal interpretation of food intake can be misleading, since due to memory issues or dietary restraints the amount of food actually ingested can be over- or underestimated. In their works, Duffy et al. revealed that food liking questionnaires represent an efficient and simple screening tool to assess diet-disease relationships. Therefore, assessing food preferences through questionnaires could be more successful than dietary measures at identifying connections with caries development, as demonstrated in our study.

Overall, our results underline that genetic factors may contribute to caries predisposition (i.e., the role of taste receptors genes) and also highlight the importance of food liking as a predictor of dental caries risk. Thus, this study indicates the importance of understanding the role of taste preferences in dental caries risk and the utility of a genetic approach that, by characterizing the genes involved in taste perception and dental caries, may contribute to identify people at risk and to develop targeted preventive strategies before the onset of caries.

Nevertheless, additional studies are needed to further confirm our findings, by taking into consideration also others factors influencing the sugars-caries relationship, such as oral hygiene, socioeconomic status, and fluoride exposure, which were not taken into account in our study.

Acknowledgments We would like to acknowledge Professor Beverly J. Tepper for critical comments. We thank all the individuals who participated in the Friuli-Venezia Giulia Genetic Park project. This study was partially supported by Fondo Trieste (2008) and Regione FVG (L.26.2008). The funders had no role in study design, data collection and analysis, decision to publish, or preparation of the manuscript.

\section{Compliance with ethical standards}

Conflict of interest Antonietta Robino, Lorenzo Bevilacqua, Nicola Pirastu, Roberta Situlin, Roberto Di Lenarda, Chiara Ottavia Navarra, and Paolo Gasparini declare that they have not conflict of interest.

Ethical standard All procedures followed were in accordance with the ethical standards of the responsible committee on human experimentation (institutional and national) and with the Declaration of Helsinki 1975, as revised in 2000 .

Informed consent Informed consent was obtained from all patients for being included in the study.

\section{References}

Allen AL, McGeary JE, Knopik VS, Hayes JE (2013) Bitterness of the non-nutritive sweetener acesulfame potassium varies with polymorphisms in TAS2R9 and TAS2R31. Chem Senses 38:379-389. doi:10.1093/chemse/bjt017

Allen AL, McGeary JE, Hayes JE (2014) Polymorphisms in TRPV1 and TAS2Rs associate with sensations from sampled ethanol. Alcohol Clin Exp Res 38:2550-2560. doi:10.1111/acer.12527

Arnadottir IB, Rozier RG, Saemundsson SR, Sigurjons H, Holbrook WP (1998) Approximal caries and sugar consumption in Icelandic teenagers. Community Dent Oral Epidemiol 26:115-121. doi:10.1111/j.1600-0528.1998.tb01937.x

Aulchenko YS, Ripke S, Isaacs A, van Duijn CM (2007) GenABEL: an R library for genome-wide association analysis. Bioinformatics 23:1294-1296. doi:10.1093/bioinformatics/btm108

Azevedo LF, Pecharki GD, Brancher JA, Cordeiro CA Jr, Medeiros KG, Antunes AA, Arruda ES, Werneck RI, de Azevedo LR, Mazur RF, Moysés SJ, Moysés ST, Faucz FR, Trevilatto PC (2010) Analysis of the association between lactotransferrin (LTF) gene polymorphism and dental caries. J Appl Oral Sci 18:166-170. doi:10.1590/S1678-77572010000200011

Beighton D, Adamson A, Rugg-Gunn A (1996) Associations between dietary intake, dental caries experience and salivary bacterial levels in 12-year-old English school children. Arch Oral Biol 41:271-280. doi:10.1016/0003-9969(96)84555-9

Bernabé E, Sheiham A (2014) Age, period and cohort trends in caries of permanent teeth in four developed countries. Am J Public Health 104:e115-e121. doi:10.2105/AJPH.2014.301869

Bretz WA, Corby PM, Schork NJ, Robinson MT, Coelho M, Costa S, Melo Filho MR, Weyant RJ, Hart TC (2005) Longitudinal 
analysis of heritability for dental caries traits. J Dent Res 84:1047-1051. doi:10.1177/154405910508401115

Bretz WA, Corby PM, Melo MR, Coelho MQ, Costa SM, Robinson M, Schork NJ, Drewnowski A, Hart TC (2006) Heritability estimates for dental caries and sucrose sweetness preference. Arch Oral Biol 51:1156-1160. doi:10.1016/j.archoralbio.2006. 06.003

Broadbent JM, Thomson WM, Poulton R (2006) Progression of dental caries and tooth loss between the third and fourth decades of life: a birth cohort study. Caries Res 40:459-465. doi:10.1159/ 000095643

Broadbent JM, Foster Page LA, Thomson WM, Poulton R (2013) Permanent dentition caries through the first half of life. Br Dent J 215:E12. doi:10.1038/sj.bdj.2013.991

Brown GK (2000) Glucose transporters: structure, function and consequences of deficiency. J Inherit Metab Dis 23(3):237-246. doi:10.1023/A:1005632012591

Bruening KS, Gilbride JA, Passannante MR, McClowry S (1999) Dietary intake and health outcomes among young children attending 2 urban day-care centers. J Am Diet Assoc 99:1529-1535. doi:10.1016/S0002-8223(99)00375-2

Burt BA, Eklund SA, Morgan KJ, Larkin FE, Guire KE, Brown LO, Weintraub JA (1988) The effects of sugars intake and frequency of ingestion on dental caries increment in a three-year longitudinal study. J Dent Res 67:1422-1429. doi:10.1177/ 00220345880670111201

Colares-Bento FC, Souza VC, Toledo JO, Moraes CF, Alho CS, Lima RM, Cordova C, Nobrega OT (2012) Implication of the G145C polymorphism (rs713598) of the TAS2r38 gene on food consumption by Brazilian older women. Arch Gerontol Geriatr 54:e13-e18. doi:10.1016/j.archger.2011.05.019

Conry JP, Messer LB, Boraas JC, Aeppli DP, Bouchard TJ Jr (1993) Dental caries and treatment characteristics in human twins reared apart. Arch Oral Biol 38:937-943. doi:10.1016/00039969(93)90106-V

Creedon MI, O'Mullane DM (2001) Factors affecting caries levels amongst 5-year-old children in County Kerry, Ireland. Community Dent Health 18:72-78

Deeley K, Letra A, Rose EK, Brandon CA, Resick JM, Marazita ML, Vieira AR (2008) Possible association of amelogenin to high caries experience in a Guatemalan-Mayan population. Caries Res 42:8-13. doi:10.1159/000111744

Dinehart ME, Hayes JE, Bartoshuk LM, Lanier SL, Duffy VB (2006) Bitter taste markers explain variability in vegetable sweetness, bitterness, and intake. Physiol Behav 87:304-313. doi:10.1016/j. physbeh.2005.10.018

Duffy VB, Davidson AC, Kidd JR, Kidd KK, Speed WC, Pakstis AJ, Reed DR, Snyder DJ, Bartoshuk LM (2004) Bitter receptor gene (TAS2R38), 6- $n$-propylthiouracil (PROP) bitterness and alcohol intake. Alcohol Clin Exp Res 28(11):1629-1637. doi:10.1097/ 01.ALC.0000145789.55183.D4

Duffy VB, Lanier SA, Hutchins HL, Pescatello LS, Johnson MK, Bartoshuk LM (2007) Food preference questionnaire as a screening tool for assessing dietary risk of cardiovascular disease within health risk appraisals. J Am Diet Assoc 107:237-245. doi:10.1016/j.jada.2006.11.005

Duffy VB, Hayes JE, Sullivan BS, Faghri P (2009) Surveying food and beverage liking: a tool for epidemiological studies to connect chemosensation with health outcomes. Ann N Y Acad Sci 1170:558-568. doi:10.1111/j.1749-6632.2009.04593.x

Duffy VB, Hayes JE, Davidson AC, Kidd JR, Kidd KK, Bartoshuk LM (2010) Vegetable intake in college-aged adults is explained by oral sensory phenotypes and TAS2R38 genotype. Chemosens Percept 3:137-148. doi:10.1007/s12078-010-9079-8

Eny KM, Wolever TM, Fontaine-Bisson B, El-Sohemy A (2008) Genetic variant in the glucose transporter type 2 is associated with higher intakes of sugars in two distinct populations. Physiol Genom 33:355-360. doi:10.1152/physiolgenomics.00148.2007

Eny KM, Wolever TM, Corey PN, El-Sohemy A (2010) Genetic variation in TAS1R2 (Ile191 Val) is associated with consumption of sugars in overweight and obese individuals in 2 distinct populations. Am J Clin Nutr 92:1501-1510. doi:10.3945/ajcn. 2010.29836

Esko T, Mezzavilla M, Nelis M, Borel C, Debniak T, Jakkula E, Julia A, Karachanak S, Khrunin A, Kisfali P, Krulisova V, Aušrelé Kučinskiené Z, Rehnström K, Traglia M, Nikitina-Zake L, Zimprich F, Antonarakis SE, Estivill X, Glavač D, Gut I, Klovins J, Krawczak M, Kučinskas V, Lathrop M, Macek M, Marsal S, Meitinger T, Melegh B, Limborska S, Lubinski J, Paolotie A, Schreiber S, Toncheva D, Toniolo D, Wichmann HE, Zimprich A, Metspalu M, Gasparini P, Metspalu A, D'Adamo P (2013) Genetic characterization of northeastern Italian population isolates in the context of broader European genetic diversity. Eur J Hum Genet 21:659-665. doi:10.1038/ejhg.2012.229

Gibson S, Williams S (1999) Dental caries in pre-school children: associations with social class, toothbrushing habit and consumption of sugars and sugar-containing foods. Further analysis of data from the National Diet and Nutrition Survey of children aged 1.5-4.5 years. Caries Res 33:101-113. doi:10.1159/ 000016503

Hayes JE, Wallace MR, Knopik VS, Herbstman DM, Bartoshuk LM, Duffy VB (2011) Allelic variation in TAS2R bitter receptor genes associates with variation in sensations from and ingestive behaviors toward common bitter beverages in adults. Chem Senses 36:311-319. doi:10.1093/chemse/bjq132

Hayes JE, Feeney EL, Allen AL (2013) Do polymorphisms in chemosensory genes matter for human ingestive behavior? Food Qual Prefer 30(2):202-216. doi:10.1016/j.foodqual.2013.05.013

Hefti A, Schmid R (1979) Effect on caries incidence in rats of increasing dietary sucrose levels. Caries Res 13:298-300. doi:10. $1159 / 000260414$

Holst D, Schuller AA, Aleksejuniené J, Eriksen HM (2001) Caries in populations-a theoretical, causal approach. Eur J Oral Sci 109:143-148. doi:10.1034/j.1600-0722.2001.00022.x

Howie B, Fuchsberger C, Stephens M, Marchini J, Abecasis GR (2012) Fast and accurate genotype imputation in genome-wide association studies through pre-phasing. Nat Genet 44:955-959. doi: 10.1038/ng.2354

Jamel HA, Sheiham A, Watt RG, Cowell CR (1997) Sweet preference, consumption of sweet tea and dental caries; studies in urban and rural Iraqi populations. Int Dent J 47:213-217. doi:10.1111/j.1875-595X.1997.tb00452.x

Jones C, Woods K, Whittle G, Worthington H, Taylor G (1999) Sugar, drinks, deprivation and dental caries in 14-year-old children in the north west of England in 1995. Community Dent Health 16:68-71

Kalsbeek H, Verrips GH (1994) Consumption of sweet snacks and caries experience of primary school children. Caries Res 28:477-483. doi:10.1159/000262023

Keller KL, Steinmann L, Nurse RJ, Tepper BJ (2002) Genetic taste sensitivity to 6- $n$-propylthiouracil influences food preference and reported intake in preschool children. Appetite 38:3-12. doi:10. 1006/appe.2001.0441

Kim U, Jorgenson E, Coon H, Leppert M, Risch N, Drayna D (2003) Positional cloning of the human quantitative trait locus underlying taste sensitivity to phenylthiocarbamide. Science 299:1221-1225. doi:10.1126/science. 1080190

Krasse B (2001) The Vipeholm dental caries study: recollections and reflections 50 years later. J Dent Res 80:1785-1788. doi:10. $1177 / 00220345010800090201$

Küchler EC, Deeley K, Ho B, Linkowski S, Meyer C, Noel J, Kouzbari MZ, Bezamat M, Granjeiro JM, Antunes LS, Antunes 
LA, de Abreu FV, Costa MC, Tannure PN, Seymen F, Koruyucu M, Patir A, Mereb JC, Poletta FA, Castilla EE, Orioli IM, Marazita ML, Vieira AR (2013) Genetic mapping of high caries experience on human chromosome 13. BMC Med Genet 14:116. doi:10.1186/1471-2350-14-116

Kulkarni GV, Chng T, Eny KM, Nielsen D, Wessman C, El-Sohemy A (2013) Association of GLUT2 and TAS1R2 genotypes with risk for dental caries. Caries Res 47:219-225. doi:10.1186/14712350-14-116

Lim S, Sohn W, Burt BA, Sandretto AM, Kolker JL, Marshall TA, Ismail AI (2008) Cariogenicity of soft drinks, milk and fruit juice in low-income African-American children: a longitudinal study. J Am Dent Assoc 139:959-967. doi:10.14219/jada.archive.2008. 0283

MacEntee MI, Clark DC, Glick N (1993) Predictors of caries in old age. Gerodontology 10:90-97. doi:10.1111/j.1741-2358.1993. tb00088.x

Marcenes W, Kassebaum NJ, Bernabé E, Flaxman A, Naghavi M, Lopez A, Murray CJ (2013) Global burden of oral conditions in 1990-2010: a systematic analysis. J Dent Res 92(7):592-597. doi: $10.1177 / 0022034513490168$

Martin HH, Petersen PE, Clarkson J, Newell J (2003) Global goals for oral health 2020. Int Dent J 53:285-288. doi:10.1111/j.1875595X.2003.tb00761.x

Masalin KE, Murtomaa HT, Sipila KP (1994) Dental caries risk in relation to dietary habits and dental services in two industrial populations. J Public Health Dent 54:160-166. doi:10.1111/j. 1752-7325.1994.tb01208.x

Mikx FH, Van Der Hoeven JS, Plasschaert AJ, König KG (1975) Effect of Actinomyces viscosus on the establishment and symbiosis of Streptococcus mutans and Streptococcus sanguis in SPF rats on different sucrose diets. Caries Res 9:1-20. doi:10. $1159 / 000260138$

Moynihan P, Petersen PE (2004) Diet, nutrition and the prevention of dental diseases. Public Health Nutr 7:201-226. doi:10.1079/ PHN2003589

Nelson G, Hoon MA, Chandrashekar J, Zhang Y, Ryba NJ, Zuker CS (2001) Mammalian sweet taste receptors. Cell 106(3):381-390. doi:10.1016/S0092-8674(01)00451-2

Peryam DR, Pilgrim PJ (1957) Hedonic scale method for measuring food preferences. Food Technol 11:9-14. doi:10.1002/jsfa.6993

Petersen PE (2008) World Health Organization global policy for improvement of oral health-World Health Assembly 2007. Int Dent J 58:115-121. doi:10.1111/j.1600-0528.2008.00448.x

Pirastu N, Kooyman M, Traglia M, Robino A, Willems SM, Pistis G, d'Adamo P, Amin N, d'Eustacchio A, Navarini L, Sala C, Karssen LC, van Duijn C, Toniolo D, Gasparini P (2014) Association analysis of bitter receptor genes in five isolated populations identifies a significant correlation between TAS2R43 variants and coffee liking. PLoS One 19(9):e92065. doi:10.1371/journal.pone.0092065 (eCollection 2014)

Sacerdote C, Guarrera S, Smith GD, Grioni S, Krogh V, Masala G, Mattiello A, Palli D, Panico S, Tumino R, Veglia F, Matullo G, Vineis P (2007) Lactase persistence and bitter taste response: instrumental variables and mendelian randomization in epidemiologic studies of dietary factors and cancer risk. Am J Epidemiol 1(166):576-581. doi:10.1093/aje/kwm113

Schmidt LE, Cox MS, Buzzard IM, Cleary PA (1994) Reproducibility of a comprehensive diet history in the Diabetes Control and Complications Trial. The DCCT Research Group. J Am Diet Assoc 94:1392-1397. doi:10.1016/0002-8223(94)92541-0

Shiffman D, O'Meara ES, Bare LA, Rowland CM, Louie JZ, Arellano AR, Lumley T, Rice K, Iakoubova O, Luke MM, Young BA, Malloy MJ, Kane JP, Ellis SG, Tracy RP, Devlin JJ, Psaty BM (2008) Association of gene variants with incident myocardial infarction in the Cardiovascular Health Study. Arterioscler
Thromb Vasc Biol 28:173-179. doi:10.1161/ATVBAHA.107. 153981

Slayton RL, Cooper ME, Marazita ML (2005) Tuftelin, mutans streptococci, and dental caries susceptibility. J Dent Res 84:711-714. doi: $10.1177 / 154405910508400805$

Sreebny LM (1982) Sugar availability, sugar consumption and dental caries. Community Dent Oral Epidemiol 10:1-7. doi:10.1111/j. 1600-0528.1982.tb00352.x

Steiner JE, Sgan-Cohen HD, Nahas J (1984) Sweet preference and dental caries among Bedouin youth in Israel. Community Dent Oral Epidemiol 12:386-389. doi:10.1111/j.1600-0528.1984. tb01477.x

Szpunar SM, Eklund SA, Burt BA (1995) Sugar consumption and caries risk in schoolchildren with low caries experience. Community Dent Oral Epidemiol 23:142-146. doi:10.1111/j. 1600-0528.1995.tb00218.x

Tepper BJ (2008) Nutritional implications of genetic taste variation: the role of PROP sensitivity and other taste phenotypes. Annu Rev Nutr 28:367-388. doi:10.1146/annurev.nutr.28.061807. 155458

Touger-Decker R, Mobley CC (2003) Position of the American Dietetic Association: oral health and nutrition. J Am Diet Assoc 103:615-625. doi:10.1053/jada.2003.50130

Vanobbergen J, Martens L, Lesaffre E, Bogaerts K, Declerck D (2001) The value of a baseline caries risk assessment model in the primary dentition for the prediction of caries incidence in the permanent dentition. Caries Res 35:442-450. doi:10.1159/ 000047488

Vos T, Flaxman AD, Naghavi M, Lozano R, Michaud C, Ezzati M, Shibuya K, Salomon JA, Abdalla S, Aboyans V, Abraham J, Ackerman I, Aggarwal R, Ahn SY, Ali MK, Alvarado M, Anderson HR, Anderson LM, Andrews KG, Atkinson C, Baddour LM, Bahalim AN, Barker-Collo S, Barrero LH, Bartels DH, Basáñez MG, Baxter A, Bell ML, Benjamin EJ, Bennett D, Bernabé E, Bhalla K, Bhandari B, Bikbov B, Bin Abdulhak A, Birbeck G, Black JA, Blencowe H, Blore JD, Blyth F, Bolliger I, Bonaventure A, Boufous S, Bourne R, Boussinesq M, Braithwaite T, Brayne C, Bridgett L, Brooker S, Brooks P, Brugha TS, Bryan-Hancock C, Bucello C, Buchbinder R, Buckle G, Budke CM, Burch M, Burney P, Burstein R, Calabria B, Campbell B, Canter CE, Carabin H, Carapetis J, Carmona L, Cella C, Charlson F, Chen H, Cheng AT, Chou D, Chugh SS, Coffeng LE, Colan SD, Colquhoun S, Colson KE, Condon J, Connor MD, Cooper LT, Corriere M, Cortinovis M, de Vaccaro KC, Couser W, Cowie BC, Criqui MH, Cross M, Dabhadkar KC, Dahiya M, Dahodwala N, Damsere-Derry J, Danaei G, Davis A, De Leo D, Degenhardt L, Dellavalle R, Delossantos A, Denenberg J, Derrett S, Des Jarlais DC, Dharmaratne SD, Dherani M, DiazTorne C, Dolk H, Dorsey ER, Driscoll T, Duber H, Ebel B, Edmond K, Elbaz A, Ali SE, Erskine H, Erwin PJ, Espindola P, Ewoigbokhan SE, Farzadfar F, Feigin V, Felson DT, Ferrari A, Ferri CP, Fèvre EM, Finucane MM, Flaxman S, Flood L, Foreman K, Forouzanfar MH, Fowkes FG, Franklin R, Fransen M, Freeman MK, Gabbe BJ, Gabriel SE, Gakidou E, Ganatra HA, Garcia B, Gaspari F, Gillum RF, Gmel G, Gosselin R, Grainger R, Groeger J, Guillemin F, Gunnell D, Gupta R, Haagsma J, Hagan H, Halasa YA, Hall W, Haring D, Haro JM, Harrison JE, Havmoeller R, Hay RJ, Higashi H, Hill C, Hoen B, Hoffman H, Hotez PJ, Hoy D, Huang JJ, Ibeanusi SE, Jacobsen KH, James SL, Jarvis D, Jasrasaria R, Jayaraman S, Johns N, Jonas JB, Karthikeyan G, Kassebaum N, Kawakami N, Keren A, Khoo JP, King CH, Knowlton LM, Kobusingye O, Koranteng A, Krishnamurthi R, Lalloo R, Laslett LL, Lathlean T, Leasher JL, Lee YY, Leigh J, Lim SS, Limb E, Lin JK, Lipnick M, Lipshultz SE, Liu W, Loane M, Ohno SL, Lyons R, Ma J, Mabweijano J, MacIntyre MF, Malekzadeh R, Mallinger L, Manivannan S, 
Marcenes W, March L, Margolis DJ, Marks GB, Marks R, Matsumori A, Matzopoulos R, Mayosi BM, McAnulty JH, McDermott MM, McGill N, McGrath J, Medina-Mora ME, Meltzer M, Mensah GA, Merriman TR, Meyer AC, Miglioli V, Miller M, Miller TR, Mitchell PB, Mocumbi AO, Moffitt TE, Mokdad AA, Monasta L, Montico M, Moradi-Lakeh M, Moran A, Morawska L, Mori R, Murdoch ME, Mwaniki MK, Naidoo K, Nair MN, Naldi L, Narayan KM, Nelson PK, Nelson RG, Nevitt MC, Newton CR, Nolte S, Norman P, Norman R, O'Donnell M, O'Hanlon S, Olives C, Omer SB, Ortblad K, Osborne R, Ozgediz D, Page A, Pahari B, Pandian JD, Rivero AP, Patten SB, Pearce N, Padilla RP, Perez-Ruiz F, Perico N, Pesudovs K, Phillips D, Phillips MR, Pierce K, Pion S, Polanczyk GV, Polinder S, Pope CA 3rd, Popova S, Porrini E, Pourmalek F, Prince M, Pullan RL, Ramaiah KD, Ranganathan D, Razavi H, Regan M, Rehm JT, Rein DB, Remuzzi G, Richardson K, Rivara FP, Roberts T, Robinson C, De Leòn FR, Ronfani L, Room R, Rosenfeld LC, Rushton L, Sacco RL, Saha S, Sampson U, Sanchez-Riera L, Sanman E, Schwebel DC, Scott JG, Segui-Gomez M, Shahraz S, Shepard DS, Shin H, Shivakoti R, Singh D, Singh GM, Singh JA, Singleton J, Sleet DA, Sliwa K, Smith E, Smith JL, Stapelberg NJ, Steer A, Steiner T, Stolk WA, Stovner LJ, Sudfeld C, Syed S, Tamburlini G, Tavakkoli M, Taylor HR, Taylor JA, Taylor WJ, Thomas B, Thomson WM, Thurston GD, Tleyjeh IM, Tonelli M, Towbin JA, Truelsen T, Tsilimbaris MK,
Ubeda C, Undurraga EA, van der Werf MJ, van Os J, Vavilala MS, Venketasubramanian N, Wang $\mathrm{M}$, Wang W, Watt K, Weatherall DJ, Weinstock MA, Weintraub R, Weisskopf MG, Weissman MM, White RA, Whiteford H, Wiersma ST, Wilkinson JD, Williams HC, Williams SR, Witt E, Wolfe F, Woolf AD, Wulf S, Yeh PH, Zaidi AK, Zheng ZJ, Zonies D, Lopez AD, Murray CJ, AlMazroa MA, Memish ZA (2012) Years lived with disability (YLDs) for 1160 sequelae of 289 diseases and injuries 1990-2010: a systematic analysis for the Global Burden of Disease Study 2010. Lancet 380:2163-2196. doi:10.1016/ S0140-6736(12)61729-2

Wang X, Shaffer JR, Zeng Z, Begum F, Vieira AR, Noel J, Anjomshoaa I, Cuenco KT, Lee MK, Beck J, Boerwinkle E, Cornelis MC, Hu FB, Crosslin DR, Laurie CC, Nelson SC, Doheny KF, Pugh EW, Polk DE, Weyant RJ, Crout R, McNeil DW, Weeks DE, Feingold E, Marazita ML (2012) Genome-wide association scan of dental caries in the permanent dentition. BMC Oral Health 12:57. doi:10.1186/1472-6831-12-57

Wendell S, Wang X, Brown M, Cooper ME, DeSensi RS, Weyant RJ, Crout R, McNeil DW, Marazita ML (2010) Taste genes associated with dental caries. J Dent Res 89:1198-1202. doi: $10.1177 / 0022034510381502$ 